\title{
Effect of colostrum feeding strategies on the expression of neuroendocrine genes and active gut mucosa-attached bacterial populations in neonatal calves
}

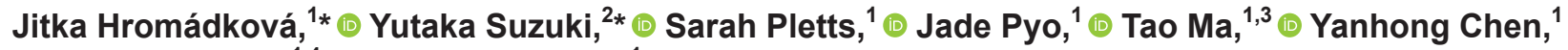

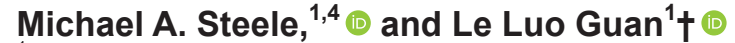 \\ ${ }^{1}$ Department of Agricultural, Food and Nutritional Science, University of Alberta, Edmonton, Alberta, Canada T6G 2P5 \\ ${ }^{2}$ Laboratory of Animal Function and Nutrition, Research Faculty of Agriculture, Hokkaido University, Sapporo, Japan 060-8589 \\ ${ }^{3}$ Key Laboratory of Feed Biotechnology of the Ministry of Agriculture and Rural Affairs, Feed Research Institute, \\ Chinese Academy of Agricultural Sciences, Beijing, China 100081 \\ ${ }^{4}$ Department of Animal Biosciences, University of Guelph, Guelph, Ontario, Canada N1G 2W1
}

\begin{abstract}
Colostrum feeding is vital for the development of the immune system and gastrointestinal tract in neonatal calves; however, it is currently unknown whether different colostrum feeding strategies affect their neuroendocrine system and potentially the gut-brain axis. The present study investigated the effect of 3 different colostrum feeding regimens on the expression of neuroendocrine genes in adrenal glands and gastrointestinal tissues and on the abundance of intestinal commensal bacteria. Holstein bull calves were fed colostrum immediately after birth and randomly assigned to 3 groups: whole milk $(\mathrm{n}=8)$, mixture of $50 \%$ colostrum and $50 \%$ whole milk $(\mathrm{n}=8)$, and colostrum $(\mathrm{CF} ; \mathrm{n}=8)$ for $72 \mathrm{~h}$ with 12-h intervals. Adrenal glands, ileum, and colon tissues were collected at $75 \mathrm{~h}$ and were subjected to the expression of 11 targeted neuroendocrine genes and the abundance of tissue mucosa-associated bacteria measurement using quantitative real-time PCR and quantitative PCR, respectively. The expressions of all targeted genes were detected, and the expression of $\alpha$-adrenergic receptor $(A D R A 1 A)$ gene was affected by $\mathrm{CF}$ in adrenal glands and gut tissues. In addition, CF upregulated the expression of HTR4 (serotonin receptor) and $S L C 4 A_{4}$ (serotonin transporter) genes in the ileum and increased the abundance of active Lactobacillus spp. and Escherichia coli (as detected at RNA level) associated with ileum and colon tissue. Furthermore, there were positive correlations between the abundance of active Lactobacillus spp. and E. coli with expression
\end{abstract}

\footnotetext{
Received October 6, 2019.

Accepted April 21, 2020.

*These authors contributed equally to this work.

†Corresponding author: lguan@ualberta.ca
}

of HTR2B and HTR4 genes in the colon, suggesting that extended colostrum feeding strategies may affect the interaction between gut microbiota and host endocrine functions in neonatal calves.

Key words: colostrum feeding, neuroendocrine, mucosa-associated microbiota, neonatal calf

\section{INTRODUCTION}

Newborn calves lack immunocompetence (Hulbert and Moisá, 2016), and their development of acquired immunity largely relies on the transfer of immunoglobulins (mainly $\operatorname{Ig} \mathrm{G}$ ) from colostrum (Hammon et al., 2013). Colostrum also induces the maturation of the gastrointestinal tract (Hammon et al., 2013), because it contains hormones and growth factors. Recent studies have also revealed that colostrum feeding can promote bifidobacterial colonization in the ileum and reduce the colonization of opportunistic pathogenic organisms in both the ileum and colon of dairy calves (Malmuthuge et al., 2015; Song et al., 2019). In addition, the timing of colostrum is important, because delayed colostrum feeding can affect passive transfer of IgG (Fischer et al., 2018). Therefore, feeding adequate amounts of colostrum in the first hours of life has been largely recommended to support neonatal calf development and adaption to extrauterine life.

To date, most studies have focused on the effect of colostrum feeding on metabolic and hormonal changes in newborn calves. For instance, calves fed colostrum immediately after birth had higher concentrations of plasma glucose, bilirubin, insulin, and insulin-like growth factors compared with calves fed colostrum on d 2, suggesting that colostrum intake stimulates systemic metabolic regulation (Hadorn et al., 1997). Similarly, restriction of colostrum and milk feeding in preweaned calves resulted in increased concentrations 
of cholesterol, albumin, and cortisol, and reduced insulin in plasma (Hammon et al., 2002). However, it is unknown whether colostrum feeding can affect the calf neuroendocrine system, which is capable of producing hormones/neurotransmitters (Toni, 2004). The hypothalamic-pituitary-adrenal and sympathetic-adrenal-medullary axes, a major neuroendocrine system that regulates stress response (Smith and Vale, 2006), are underdeveloped at birth but develop simultaneously with the immune system to make animals immunocompetent and resilient (Hulbert and Moisá, 2016). Serotonin signaling partly mediates gut-brain axis, and promotes postnatal development of gut function, such as cell proliferation and gut motility (Tharayil et al., 2010; Spohn et al., 2016). Although the neuroendocrine system is important in the systemic regulation of metabolism and immunity via endocrine pathway and neuro-transmission, our understanding of such systems in ruminants is limited, especially regarding whether colostrum feeding strategies affect local neuroendocrine function in adrenal glands and intestinal tissues in neonatal calves.

In the gut, diverse microbial populations colonize the mucosal surface and play an important role in modulating the host's immune functions (Mulder et al., 2011). Recent emerging evidence has revealed the role of gut microbiota on the gut-brain axis, as shifts in gut microbiota can affect peripheral serotonin (5-hydroxytryptamine) production and alter cytokine production, which affects neurophysiology, and butyrate, a microbial product that directly affects cell activities involved in the brain and gut barrier (Smith, 2015). It has also been reported that the supplementation of Bifidobacteria to mice and humans reduces their stress and anxiety (Allen et al., 2016; Moya-Pérez et al., 2017). We hypothesized that the enhanced gut Bifidobacteria colonization by colostrum feeding could therefore induce proper neuroendocrine function (mainly lower the stress level) in calves. However, the relationship among different colostrum feeding strategies, gut microbiota, and host endocrine production in calves has not been studied.

Commonly, calves are fed milk or milk replacer after the first colostrum feeding on farm (Vasseur et al., 2010). Given that colostrum has positive effects on gut health of animals, as stated above, we hypothesize that extending colostrum feeding could potentially benefit calves by enhancing their neuroendocrine functions and promoting the growth of beneficial bacteria in the gut. Therefore, the primary objective of the present study was to investigate the effect of extended colostrum feeding on the expression of neuroendocrine genes in the adrenal gland and gut tissues and the mucosa-attached bacterial colonization in neonatal calves.

\section{MATERIALS AND METHODS}

\section{Animal Study}

The animal study was performed at the Dairy Research and Technology Centre of the University of Alberta from January to August of 2017. All procedures were performed following the Canadian Council on Animal Care guidelines and were approved by Animal Care and Use Committee, University of Alberta (AUP00001595).

This is a companion study to Inabu et al. (2019) and Pyo et al. (2020), in which the management of animals and experimental design is described in greater detail. Briefly, Holstein bull calves $(\mathrm{n}=24)$ with an average BW of $42.7 \pm 1.8 \mathrm{~kg}$ were separated from their dams at birth and housed in individual pens. They were fed pasteurized, pooled colostrum containing $62 \mathrm{~g}$ of IgG/L (Saskatoon Colostrum Company Ltd., Saskatoon, SK, Canada) at $7.5 \% \mathrm{BW}$ within $1 \mathrm{~h}$ of life using nipple bottles. From the second feeding, calves were randomly assigned to 1 of 3 feeding management groups: whole milk (WM; $\mathrm{n}=8$ ); mixture of $50 \%$ colostrum and $50 \%$ whole milk (CM; $\mathrm{n}=8)$; or colostrum $(\mathbf{C F} ; \mathrm{n}=8)$, with all meals fed at $5 \%$ of BW. Pooled whole milk was obtained from cows at the Dairy Research and Technology Centre. All calves received their second feeding $10 \mathrm{~h}$ after the first colostrum feeding, and subsequent meals were provided every $12 \mathrm{~h}$ until $72 \mathrm{~h}$ of life. All animals were euthanized at $75 \mathrm{~h}$ of life by administrating Euthanyl (30 mg of pentobarbital/kg of $75-\mathrm{h}$ BW; Vetoquinol, Lavaltrie, QC, Canada), following the procedures described by Pyo et al. (2020). Ileum, colon, and right and left adrenal gland tissues were collected within $30 \mathrm{~min}$ after euthanasia using sterile dissection tools and following the steps as described by Pyo et al. (2020). Samples were rinsed 3 times with sterile phosphate buffered saline ( $\mathrm{pH} 7.0)$, immediately frozen using liquid nitrogen, and stored at $-80^{\circ} \mathrm{C}$ until further analysis.

\section{RNA Extraction}

Tissue samples were ground into fine powder under liquid nitrogen before RNA isolation. Total RNA $(\sim 0.1$ g) from adrenal glands, ileum, and colon tissues was extracted with TRIzol reagent (Invitrogen, Carlsbad, CA) according to the manufacturer's procedures. Assessment of RNA integrity and quantity was performed using Agilent 2200 TapeStation (Agilent Technologies, Santa Clara, CA) and Qubit 3.0 Fluorometer (Invitrogen). Samples exhibiting integrity values greater than 7.0 were used for further analysis of gene expression and gut bacterial abundance. 


\section{Gene Selection and Primer Design}

Sequences of mRNA for 11 targeted genes related to the neuroendocrine system of Bos taurus species were obtained through National Center of Biotechnology Information (www.ncbi.nlm.nih.gov). Among them, genes encoding steroidogenic acute regulatory protein $(\boldsymbol{S t A R})$ and cytochrome P450, subfamily XI B, polypeptide 1 (CYP11B1), which are key enzymes in steroid and glucocorticoid production, respectively, were assessed (Liu et al., 2013). In addition, 8 gene-encoding receptors for glucocorticoids, catecholamines (epinephrine and norepinephrine), adrenocorticotropic hormone $(A C T H)$, serotonin, and $\gamma$-aminobutyric acid were selected: nuclear receptor subfamily 3 group $\mathrm{C}$ member 1 (NR3C1)-encoding glucocorticoid receptor (Juszczak and Stankiewicz, 2018); melanocortin 2 receptor $(M C 2 R)$-encoding ACTH receptor (Proudnikov et al., 2008); adrenoceptor $\beta_{2}$ (ADRB2)- and adrenoceptor $\alpha_{1 \mathrm{~A}}(A D R A 1 A)$-encoding adrenergic receptors for catecholamines (Li et al., 2014); $\gamma$-aminobutyric acid type A receptor $\beta_{2}$ subunit (GABRB2)- and $\gamma$-aminobutyric acid type B receptor subunit 1 (GABBR1)-encoding receptor for neurotransmitter (Zhao et al., 2007); and 5-hydroxytryptamine receptor 2B (HTR2B)- and 5-hydroxytryptamine receptor 4 (HTR4)-encoding serotonin receptors (Corominas et al., 2010). Additionally, solute carrier family 6 member $4(S L C 6 A 4)$ geneencoding serotonin transporter was included (Nutt et al., 2015). Primers targeting the above-described genes were designed using Primer Express Software (Thermo Fisher Scientific, Waltham, MA) and were validated with in silico analysis, using the UCSC In-Silico PCR Program (Kuhn et al., 2013), followed by PCR validation (Table 1).

\section{Detection of Gene Expression Using Quantitative Real-Time PCR}

Total RNA $(1 \mu \mathrm{g})$ was reversely transcribed using iScript reverse transcription Supermix for quantitative real-time PCR kit (qRT-PCR; Bio-Rad Laboratories, Hercules, CA) to generate cDNA. Quantitative RTPCR was performed with ViiA 7 Real-Time PCR and QuantStudio 6 Real-Time PCR (Applied Biosystems, Foster City, CA) using the Fast SYBR Green Master Mix (Applied Biosystems) chemistry. All samples were analyzed in triplicate. Each reaction contained $5 \mu \mathrm{L}$ of Fast SYBR Green Master Mix, $1 \mu \mathrm{L}$ of forward primer $(20 \mathrm{pmol} / \mu \mathrm{L}), 1 \mu \mathrm{L}$ of reverse primer $(20 \mathrm{pmol} / \mu \mathrm{L}), 2$ $\mu \mathrm{L}$ of nuclease-free water, and $1 \mu \mathrm{L}$ of $\mathrm{cDNA}$ template $(2.5 \mathrm{ng} / \mu \mathrm{L})$. The reaction was carried out using the following program: $95^{\circ} \mathrm{C}$ for $20 \mathrm{~s}$ for initial denaturation; then 40 cycles of $95^{\circ} \mathrm{C}$ for $1 \mathrm{~s}$, followed by annealing/ extension for $30 \mathrm{~s}$ at $60^{\circ} \mathrm{C}$; and a final melting curve stage $\left(95^{\circ} \mathrm{C}\right.$ for $15 \mathrm{~s} ; 60^{\circ} \mathrm{C}$ for $1 \mathrm{~min} ; 95^{\circ} \mathrm{C}$ for $\left.15 \mathrm{~s}\right)$, with fluorescence detection at $0.05^{\circ} \mathrm{C}$ intervals. Melting curve analysis was performed to confirm single product amplification. Expression of 3 housekeeping genes: $A C T B$, $G A P D H$, and $18 \mathrm{~S}$ rRNA, in the ileum, colon, and adrenal glands under each treatment were analyzed using NormFinder algorithm (Wang et al., 2012). According to the statistical analysis, there are no differences of $G A P D H$ expression among tissues and treatments $(P>$ $0.05)$, whereas there is a tissue effect on the expression of 18S rRNA gene $(P<0.001)$ and a tentative effect on the expression of $A C T B$ gene $(P=0.06)$. Therefore, $G A P D H$ was used as an endogenous housekeeping gene for downstream qRT-PCR analysis. For each sample, the expression of targeted genes was presented as $\Delta \mathrm{Ct}$, calculated by subtracting the average cycle threshold (Ct) of the GAPDH from the average $\mathrm{Ct}$ of targeted genes. Differences in gene expression were evaluated by calculating $\Delta \mathrm{Ct}$ values, with higher $\Delta \mathrm{Ct}$ being lower expression and lower $\Delta \mathrm{Ct}$ being higher expression.

\section{Estimation of Active Mucosal Attached Bacteria}

The above cDNA were also used to evaluate the abundances of active total bacteria, Lactobacilli spp., Bifidobacterium spp. and E. coli through measuring their respective copy number of $16 \mathrm{~S}$ rRNA using qPCR with specific primers (Table 1). The qPCR was performed using SYBR Green chemistry with StepOnePlus Real-Time PCR System (Applied Biosystems). All reactions for total bacteria, Lactobacillus acidophilus, Bifidobacterium spp., and E. coli, were conducted with standard curve constructed out of $16 \mathrm{~S}$ DNA of Butyrivibrio hungatei, Bifidobacterium longum, and E. coli K12, respectively. The copy number of $16 \mathrm{~S} \mathrm{rRNA} / \mathrm{g}$ of tissue was calculated with an equation previously described by Malmuthuge et al. (2015). Abundance of Bifidobacterium spp. and E. coli was calculated by dividing the copy number of $16 \mathrm{~S}$ rRNA of genus/species by the copy number of total bacteria. Bifidobacterium spp. and E. coli log-transformed data were calculated as $\log _{10}$ of the copy number of $16 \mathrm{~S} \mathrm{rRNA} / \mathrm{g}$.

\section{Cortisol and Serotonin Circulating Concentrations}

Plasma samples were collected from the calves in WM, CM, and CF before euthanasia (at $72 \mathrm{~h}$ of life) and stored at $-20^{\circ} \mathrm{C}$, as described in Inabu et al. (2019). Briefly, aprotinin (Sigma-Aldrich, St. Louis, MO) was added to blood samples (in the ratio of 500 kallikrein inhibitor units:mL of blood) and centrifuged at 3,000 $\times$ 
Hromádková et al.: NEUROENDOCRINE GENE EXPRESSION IN CALVES

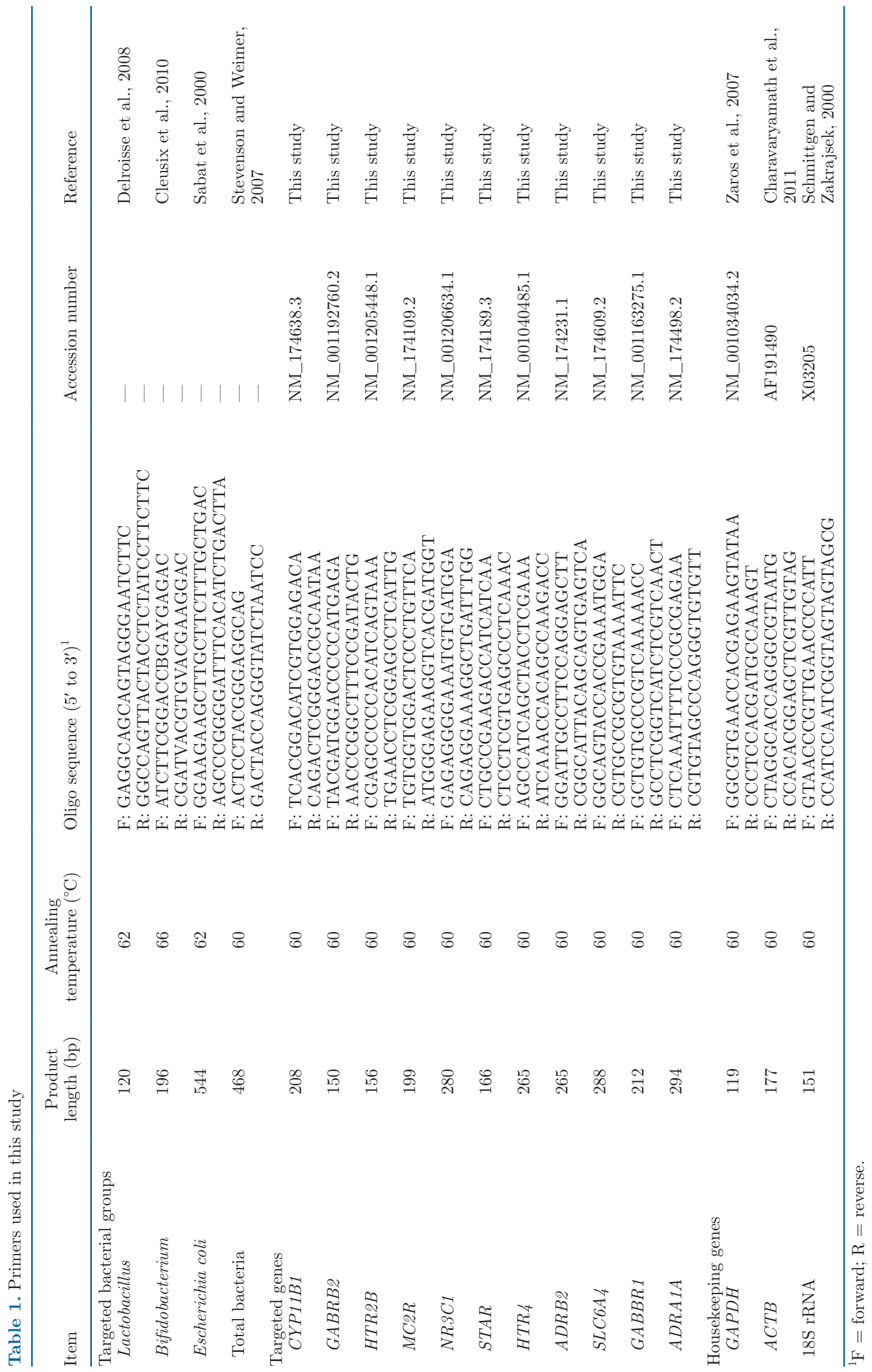


$g$ for $20 \mathrm{~min}$ at $4^{\circ} \mathrm{C}$. Plasma concentrations of cortisol and serotonin were measured using commercial ELISA kits (Cortisol ELISA, K003-H5, Arbor Assays, Ann Arbor, MI; Serotonin ELISA, ADI-900-175, Enzo Life Sciences, Farmingdale, NY), following the manual provided by the manufacturer. The intra-assay coefficients of variation for cortisol and serotonin were $4.25 \%$ and $2.11 \%$, respectively.

\section{Statistical Analysis}

The effect of treatment on the expression of genes related to the neuroendocrine system and bacterial population was evaluated using nonparametric Kruskal-Wallis test followed by Dunn's multiple comparison test in R software (https://www.r-project.org). The Benjamini-Hochberg method was used to adjust $P$ values. Significant differences were declared at $P<0.05$ and tendencies were discussed at $0.05 \leq P<0.10$. Gene expression $(\Delta \mathrm{Ct})$ and bacterial data (copy number/g of tissue) were presented in least squares means with standard error of mean. Pearson correlation in $\mathrm{R}$ software using function Rcorr was used to investigate a potential relationship between neuroendocrine gene expression, plasma hormone concentrations, and gut bacteria. Level of significance for correlation coefficients were declared at $\mathrm{r}>0.4$ or $\mathrm{r}<-0.4$ with $P<0.05$.

\section{RESULTS}

\section{Expression of Genes Involved in Neuroendocrine Functions in Adrenal Glands, Ileum, and Colon Tissues}

The expression of 11 selected genes was detected in adrenal glands, ileum, and colon tissues at $75 \mathrm{~h}$ of life (Figure 1). Among them, expression of CYP11B1 (indicated as $\Delta \mathrm{Ct},-2.22 \pm 0.14$ vs. $7.14 \pm 0.53$ or $5.61 \pm$ $0.64, P<0.001$; lower $\Delta$ Ct means higher expression), $\operatorname{STAR}(-3.11 \pm 0.09$ vs. $6.66 \pm 0.15$ or $6.24 \pm 0.49, P$ $<0.001)$, and $M C 2 R(2.56 \pm 0.09$ vs. $5.77 \pm 0.28$ or $5.34 \pm 0.67, P<0.001)$ was higher in adrenal glands compared with their expressions in the ileum and colon tissues. In contrast, higher expression of $A D R A 1 A$, $A D R B 2$, and HTR 4 was detected in ileum $(7.37 \pm 0.43$, $3.9 \pm 0.12,0.16 \pm 0.15)$ and colon $(5.61 \pm 0.64,3.71$ $\pm 0.23,-1.05 \pm 0.28)$ compared with their expression levels in adrenal gland $(9.66 \pm 0.56,5.99 \pm 0.25,7.74$ $\pm 0.28)$, respectively $(P<0.001$ for 3 genes $)$.

\section{Effect of Colostrum Feeding Strategy on Neuroendocrine Hormones and Expression of Neuroendocrine Genes}

Colostrum feeding strategies did not affect plasma concentrations of cortisol and serotonin (Figure 2).
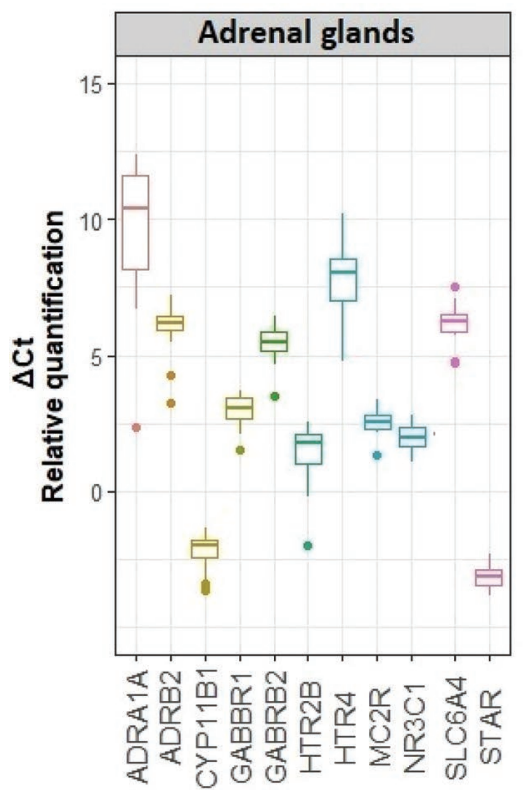
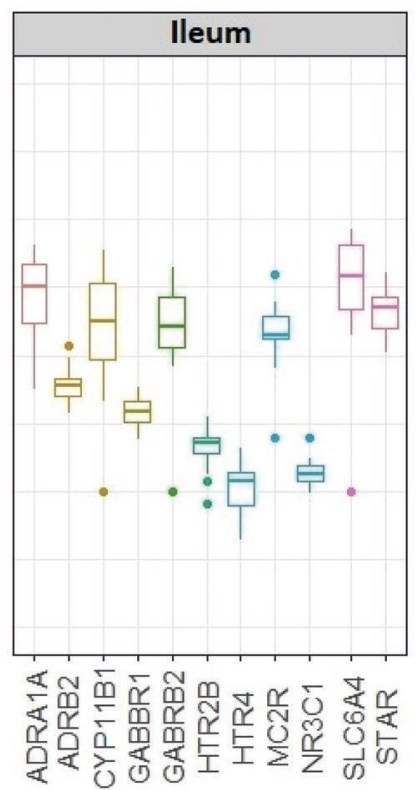

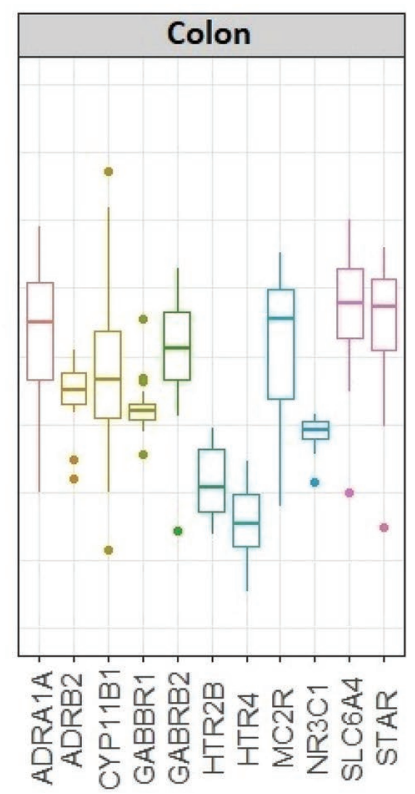

Figure 1. The detected expression of targeting genes in adrenal glands, ileum, and colon tissues using quantitative real-time PCR. The

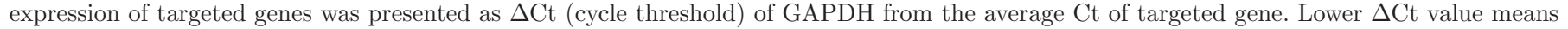

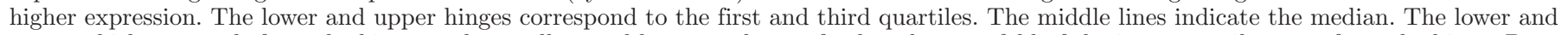
upper whisker extends from the hinge to the smallest and largest value no further than 1.5-fold of the inter-quartile range from the hinge. Data falling outside the whiskers are plotted as outliers of the data. 

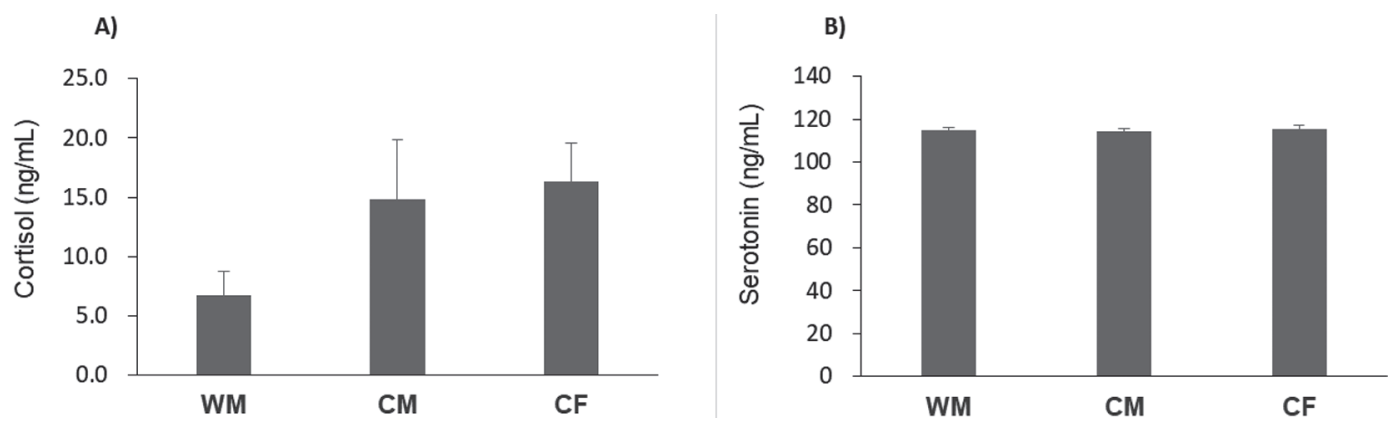

Figure 2. Plasma concentrations of (A) cortisol and (B) serotonin in calves under different colostrum and milk feeding managements (WM $=$ whole milk; $\mathrm{CM}=$ mixture of $50 \%$ colostrum and $50 \%$ milk; $\mathrm{CF}=$ colostrum feeding; $\mathrm{n}=8$ in each group). Calves were fed treatment diets at 12-h intervals after the first colostrum feeding, and blood samples were collected at $75 \mathrm{~h}$ of life. Data are presented as mean \pm SEM.

However, the expression of certain neuroendocrine genes was altered in adrenal glands and intestinal tissues (Tables 2, 3, and 4). In adrenal glands, CF-fed calves had a higher $(P=0.02)$ expression of $A D R A 1 A$ compared with WM- or CM-fed calves (Table 2), whereas the expression of StAR tended to be lower $(P$ $=0.02)$ in CM-fed calves compared with WM- or CFfed calves. No difference in expression of other genes among the 3 groups was detected. In ileal tissue, the expression of NR3C1 was lower $(P=0.01)$ in $C F$-fed calves compared with CM- and WM-fed calves (Table $3)$. The expression of $A D R A 1 A$ was higher $(P=0.03)$ in CF-fed calves compared with CM-fed calves, and a tendency of higher expression was observed in CF-fed calves compared with WM-fed calves (Table 3). In addition, the expression of $S L C 6 A 4$ in the WM-fed calves was lower $(P=0.04)$ than CM-fed and tended to be lower than $\mathrm{CF}$-fed calves. Moreover, the ileal expression of HTR 4 tended to be lower $(P=0.09)$ in WM-fed calves compared with $\mathrm{CF}$-fed calves. In colon tissue, ex- pression of $A D R A 1 A$ was higher $(P=0.03)$ in WM-fed calves compared with CM-fed calves and expression of $M C 2 R$ was lower $(P=0.02)$ in $\mathrm{CF}$-fed calves compared with CM-fed calves (Table 4).

\section{Effect of Colostrum Feeding Strategies on Abundance of Active Tissue- Associated Bacteria}

Calves fed the CF dietary treatment had higher, and a tendency for higher abundance of active mucosaattached Lactobacillus in the colon $(P=0.02)$ and ileum $(P=0.08)$, respectively, compared with calves fed WM (Table 5). In addition, calves fed CF had higher abundance of active mucosa-attached $E$. coli $(P=0.03)$ in colon compared with calves fed WM and CM, but no difference was observed in the ileum. No difference was detected in abundance of active mucosa-attached Bifidobacterium spp. in the ileum or colon among the 3 treatments.

Table 2. Effect of feeding management on expression of targeted genes in adrenal glands

\begin{tabular}{|c|c|c|c|c|}
\hline \multirow[b]{2}{*}{ Gene } & \multicolumn{3}{|c|}{ Treatment $^{1}$} & \multirow[b]{2}{*}{$P$-value } \\
\hline & WM & $\mathrm{CM}$ & $\mathrm{CF}$ & \\
\hline$A D R A 1 A$ & $10.97 \pm 0.59^{\mathrm{a}}$ & $11.04 \pm 0.41^{\mathrm{a}}$ & $7.17 \pm 0.84^{\mathrm{b}}$ & 0.02 \\
\hline$A D R B 2$ & $5.83 \pm 0.25$ & $6.23 \pm 0.17$ & $5.90 \pm 0.42$ & 0.66 \\
\hline$C Y P 11 B 1$ & $-2.12 \pm 0.18$ & $-2.02 \pm 0.24$ & $-2.50 \pm 0.30$ & 0.30 \\
\hline$G A B B R 1$ & $3.03 \pm 0.17$ & $3.15 \pm 0.16$ & $2.93 \pm 0.26$ & 0.99 \\
\hline GABRB2 & $5.68 \pm 0.18$ & $5.51 \pm 0.22$ & $5.23 \pm 0.28$ & 0.40 \\
\hline$H T R 2 B$ & $1.33 \pm 0.49$ & $1.83 \pm 0.22$ & $1.20 \pm 0.30$ & 0.47 \\
\hline$H_{4} 4$ & $7.62 \pm 0.41$ & $7.78 \pm 0.41$ & $7.83 \pm 0.66$ & 0.91 \\
\hline$M C 2 R$ & $2.47 \pm 0.21$ & $2.64 \pm 0.11$ & $2.58 \pm 0.12$ & 0.94 \\
\hline NR3C1 & $1.90 \pm 0.12$ & $1.97 \pm 0.12$ & $2.16 \pm 0.21$ & 0.28 \\
\hline$S L C 6 A 4$ & $5.92 \pm 0.22$ & $6.45 \pm 0.14$ & $6.16 \pm 0.27$ & 0.42 \\
\hline$S T A R$ & $-3.26 \pm 0.12^{\mathrm{a}}$ & $-2.76 \pm 0.15^{\mathrm{b}}$ & $-3.26 \pm 0.14^{\mathrm{a}}$ & 0.02 \\
\hline
\end{tabular}

$\overline{\mathrm{a}, \mathrm{b}}$ Different superscripts within a row indicate a significant difference among treatments $(P<0.05)$.

${ }^{1}$ Treatment for $72 \mathrm{~h}$ after birth; $\mathrm{WM}=$ whole milk; $\mathrm{CM}=$ mixture of $50 \%$ colostrum and $50 \%$ milk; $\mathrm{CF}=$ colostrum feeding; $\mathrm{n}=8$ in each group. Expressional levels are indicated as $\Delta \mathrm{Ct}$ mean $\pm \mathrm{SEM}$; Ct $=$ cycle threshold; lower value means higher expression. 
Table 3. Effect of feeding management ( $\mathrm{WM}=$ whole milk; $\mathrm{CM}=$ mixture of $50 \%$ colostrum and $50 \%$ milk; $\mathrm{CF}=$ colostrum feeding; for $72 \mathrm{~h}$ after birth; $\mathrm{n}=8$ in each group) on expression of targeted genes in ileal tissue

\begin{tabular}{|c|c|c|c|c|}
\hline \multirow[b]{2}{*}{ Gene $^{1}$} & \multicolumn{3}{|c|}{ Treatment ${ }^{2}$} & \multirow[b]{2}{*}{$P$-value } \\
\hline & WM & $\mathrm{CM}$ & $\mathrm{CF}$ & \\
\hline$A D R A 1 A$ & $7.68 \pm 0.84^{\mathrm{ab}}$ & $8.40 \pm 0.38^{\mathrm{a}}$ & $5.72 \pm 0.30^{\mathrm{b}}$ & 0.03 \\
\hline$A D R B 2$ & $3.97 \pm 0.12$ & $3.74 \pm 0.24$ & $3.98 \pm 0.24$ & 0.65 \\
\hline$C Y P 11 B 1$ & $6.88 \pm 0.57$ & $5.59 \pm 0.92$ & $4.66 \pm 1.14$ & 0.24 \\
\hline GABBR1 & $3.12 \pm 0.21$ & $2.70 \pm 0.18$ & $2.99 \pm 0.20$ & 0.26 \\
\hline GABRB2 & $6.08 \pm 0.92$ & $4.80 \pm 0.69$ & $6.57 \pm 0.51$ & 0.10 \\
\hline HTR2B & $1.70 \pm 0.35$ & $1.51 \pm 0.19$ & $1.75 \pm 0.22$ & 0.50 \\
\hline$H_{T R}$ & $0.43 \pm 0.35^{\mathrm{a}}$ & $0.26 \pm 0.21$ & $-0.21 \pm 0.19^{b}$ & 0.09 \\
\hline$M C 2 R$ & $5.53 \pm 0.53$ & $5.62 \pm 0.28$ & $6.50 \pm 0.67$ & 0.36 \\
\hline NR3C1 & $0.50 \pm 0.12^{\mathrm{a}}$ & $0.52 \pm 0.12^{\mathrm{a}}$ & $1.14 \pm 0.17^{\mathrm{b}}$ & 0.01 \\
\hline $\mathrm{SLC}_{6} \mathrm{~A}_{4}$ & $8.70 \pm 0.35^{\mathrm{a}}$ & $6.34 \pm 0.96^{\mathrm{b}}$ & $6.05 \pm 1.38^{b}$ & 0.04 \\
\hline$S t A R$ & $6.68 \pm 0.23$ & $6.58 \pm 0.18$ & $6.72 \pm 0.36$ & 0.87 \\
\hline
\end{tabular}

$\overline{\mathrm{a}, \mathrm{b}}$ Different superscripts within a row indicate a significant difference among treatments $(P<0.05)$.

${ }^{1} A D R A 1 A=$ adrenoceptor $\alpha_{1 \mathrm{~A}} ; A D R B 2=$ adrenoceptor $\beta_{2} ; C Y P 11 B 1=$ cytochrome $\mathrm{P} 450$, subfamily XI $\mathrm{B}$, polypeptide $1 ; G A B B R 1=$ gamma-aminobutyric acid type $\mathrm{B}$ receptor subunit $1 ;$ GABRB2 = gammaaminobutyric acid type A receptor beta2 subunit; $H T R 2 B=5$-hydroxytryptamine receptor $2 \mathrm{~B} ; H T R 4=5$-hydroxytryptamine receptor $4 ; M C 2 R=$ melanocortin 2 receptor; $N R 3 C 1=$ nuclear receptor subfamily 3 group $\mathrm{C}$ member $1 ; S L C 6 A 4=$ solute carrier family 6 member $4 ; S t A R=$ steroidogenic acute regulatory protein.

${ }^{2}$ Expressional levels are indicated as $\Delta \mathrm{Ct}$ mean $\pm \mathrm{SEM}$; $\mathrm{Ct}=$ cycle threshold; lower value means higher expression.

\section{Relationship Between Active Mucosal Attached Bacteria and Neuroendocrine Gene Expression and Endocrine Concentrations}

Pearson correlation analysis revealed a positive correlation $(\mathrm{r}=0.76 ; P<0.001)$ between the abundance of active mucosa-associated Lactobacillus spp. and E. coli in colon tissue (Figure 3A). The abundance of active mucosa-associated Lactobacillus spp. $(\mathrm{r}=0.41 ; P$ $=0.04$, Figure 3B) and E. coli $(\mathrm{r}=0.42, P=0.04$, Data not shown) in ileum was positively correlated with serum cortisol level. We also found a positive correlation between expression of HTR2B and HTR4, and abundance of active mucosa-attached $E$. coli $(\mathrm{r}=$ $0.77, P<0.001$ and $\mathrm{r}=0.51, P=0.01$; Figure $4 \mathrm{~A}$, B) and active mucosa-attached Lactobacillus spp. ( $\mathrm{r}$ $=0.64, P<0.001$ and $\mathrm{r}=0.57, P=0.0036$; Figure $4 \mathrm{C}, \mathrm{D})$ in colon tissue, respectively. No significant correlations were observed between abundance of active mucosa-associated bacteria and expression of targeted endocrine genes in ileum.

\section{DISCUSSION}

Colostrum plays a fundamental role in passive transfer of immunity to newborn calves, which protects the

Table 4. Effect of feeding management ( $\mathrm{WM}=$ whole milk; $\mathrm{CM}=$ mixture of $50 \%$ colostrum and $50 \%$ milk; $\mathrm{CF}=$ colostrum feeding; for $72 \mathrm{~h}$ after birth; $\mathrm{n}=8$ in each group) on expression of targeted genes in colon tissue

\begin{tabular}{|c|c|c|c|c|}
\hline \multirow[b]{2}{*}{ Gene } & \multicolumn{3}{|c|}{ Treatment $^{1}$} & \multirow[b]{2}{*}{$P$-value } \\
\hline & WM & $\mathrm{CM}$ & $\mathrm{CF}$ & \\
\hline$A D R A 1 A$ & $4.70 \pm 0.76^{\mathrm{a}}$ & $7.87 \pm 0.42^{\mathrm{b}}$ & $6.86 \pm 0.81^{\mathrm{b}}$ & 0.03 \\
\hline$A D R B 2$ & $3.34 \pm 0.35$ & $3.41 \pm 0.45$ & $4.37 \pm 0.29$ & 0.12 \\
\hline$C Y P 11 B 1$ & $5.85 \pm 0.99$ & $2.35 \pm 1.15$ & $5.12 \pm 0.91$ & 0.10 \\
\hline GABBR1 & $2.82 \pm 0.22$ & $3.52 \pm 0.44$ & $2.98 \pm 0.24$ & 0.67 \\
\hline GABRB2 & $5.97 \pm 0.58$ & $3.77 \pm 0.81$ & $6.07 \pm 0.57$ & 0.10 \\
\hline HTR2B & $0.72 \pm 0.53$ & $-0.38 \pm 0.35$ & $1.02 \pm 0.39$ & 0.11 \\
\hline$H_{T R}$ & $-1.44 \pm 0.56$ & $-1.13 \pm 0.29$ & $-0.58 \pm 0.57$ & 0.40 \\
\hline$M C 2 R$ & $5.15 \pm 0.89^{\mathrm{ab}}$ & $3.27 \pm 1.52^{\mathrm{a}}$ & $7.47 \pm 0.43^{\mathrm{b}}$ & 0.02 \\
\hline$N R 3 C 1$ & $2.12 \pm 0.16$ & $2.02 \pm 0.97$ & $2.49 \pm 0.13$ & 0.13 \\
\hline SLC6A4 & $7.11 \pm 0.71$ & $4.99 \pm 1.13$ & $7.63 \pm 0.58$ & 0.23 \\
\hline$S T A R$ & $6.47 \pm 0.80$ & $5.05 \pm 1.08$ & $7.20 \pm 0.47$ & 0.40 \\
\hline
\end{tabular}

$\overline{\mathrm{a}, \mathrm{b}}$ Different superscripts within a row indicate a significant difference among treatments $(P<0.05)$.

${ }^{1}$ Expressional levels are indicated as $\Delta \mathrm{Ct}$ mean $\pm \mathrm{SEM}$; $\mathrm{Ct}=$ cycle threshold; lower value means higher expression. 


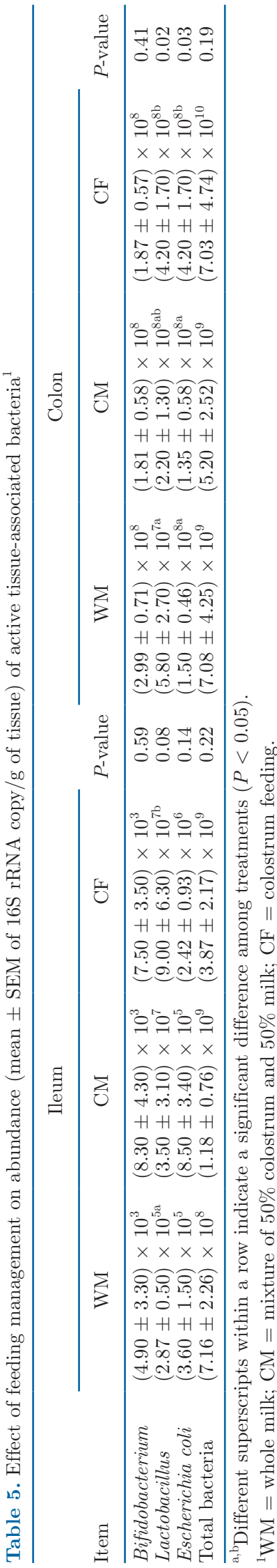

hypoagammaglobulinemic neonatal calf against pathogens and other environmental challenges (Bendixen et al., 2011). In practice, a minimum feeding of $100 \mathrm{~g}$ of IgG in colostrum is recommended to ensure successful passive transfer of immunity in neonatal calves (Weaver et al., 2000). The hypothalamic-pituitary-adrenal axis serves as the primary regulator and modulator of immunity for newborn animals without a developed adaptive immune system (Hulbert and Moisá, 2016). In this regard, how colostrum feeding regimens affect expression of neuroendocrine genes may help evaluate the efficacy of newborn calf management strategies, such as extended colostrum feeding, which may be important to ensure passive transfer of immunity if the quality of colostrum is relatively low or unknown.

Production of stress hormones occurs primarily in the adrenal glands, and other organs, such as the brain, thymus, skin, vascular system, lungs, and intestine, have the capacity to produce glucocorticoids and catecholamines locally (Eisenhofer et al., 1997; Noti et al., 2009; Pacak, 2011). However, it is currently unknown whether stress hormones are also produced by intestinal mucosa in neonatal calves. In the present study, the expression of StAR and CYP11B1 genes that encode key enzymes in steroid and glucocorticoid production were detected in ileum and colon tissues, suggesting that intestinal mucosa may produce glucocorticoids in neonatal calves. The expression of MC2R (ACTH receptor) was also detected in the calf ileum and colon, which is known to mediate stress-induced cortisol secretion in response to ACTH signal (Proudnikov et al., 2008). These results correspond with previous findings of mucosal synthesis of glucocorticoids in intestinal tissues of rodents and humans (Eisenhofer et al., 1997; Cima et al., 2004; Noti et al., 2009; Kostadinova et al., 2014), suggesting that the gut of preweaned ruminants (before rumen is developed) may have similar endocrine secretion functions as those reported in monogastric animals. The expression of StAR, CYP11B1, and MC2R was significantly higher in adrenal glands compared with the intestinal tissues in calves. This suggests that extra-adrenal glucocorticoids production may not have a great effect on the gut endocrine functions, but rather regulates local physiological processes including the gut immune system and other metabolic pathways (Kostadinova et al., 2014). In contrast, $A D R A 1 A$ and $A D R B 2$ genes, which encode $\alpha_{1^{-}}$and $\alpha_{2}$-adrenergic receptors for catecholamines (Li et al., 2014), and HTR 4 gene, which encodes the receptor for serotonin (Corominas et al., 2010), had higher expression in the mucosa of the ileum and colon compared with those in adrenal glands. It is reported that adrenergic nerve fibers are present in Peyer's patches and in nonfollicular mucosa in close proximity to immune cells, including dendritic cells and 
A)

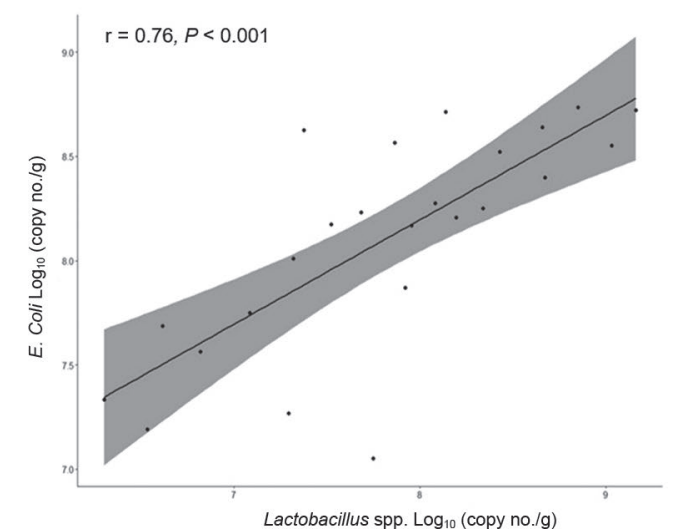

B)

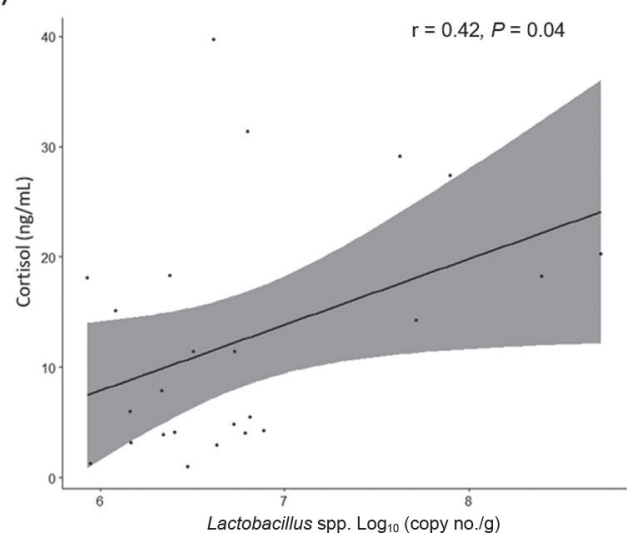

Figure 3. (A) Pearson correlation between log-transformed abundance of active tissue-associated Escherichia coli and Lactobacillus spp. in the colon of neonatal calves. (B) Pearson correlation between plasma concentration and log-transformed abundance of active tissue-associated Lactobacillus spp. in the ileum of calves. $\mathrm{r}=$ correlation coefficient; $P=$ level of significance; gray area shows $95 \%$ confidence limits.

mast cells of mucosa (Lyte et al., 2011). Meanwhile, adrenergic and serotonin receptors regulate secretion of Glucagon-like peptide-2 by enteroendocrine L cells, which increases nutrient absorption and intestinal growth (Drucker, 2001; Burrin et al., 2003; Connor et al., 2015). The higher expression of ADRA1A, ADRB2, and HTR 4 in the ileum and colon tissues in the present study might indicate the importance of these receptors in the regulation of fundamental digestive functions (e.g., intestinal vermiculation), and other physiological processes associated with gut function and mucosal immunity (Santulli et al., 2012; Hodge et al., 2013; Scanzano and Cosentino, 2015). Because calves are born with undeveloped immune systems and immature intestinal morphology (Blum, 2006; Hulbert and Moisá, 2016), the stimulation of signal transduction via these neurotransmitters may play a role in adapting to environmental changes in neonatal development.

Our study also found that feeding calves with different combinations of colostrum and milk from the second meal affected the expression of neuroendocrine genes both in adrenal glands and intestine of neonatal calves. The nutritional components of colostrum and milk differ based on their qualities, including amount of lactose, protein, and fat (McGrath et al., 2016). In addition to its nutrients, colostrum contains high concentrations of immunoglobulins, growth factors, and bioactive and immunological components (Kuhne et al., 2000). Calves fed CM had lower expressions of StAR in adrenal glands compared with calves fed $\mathrm{WM}$ and $\mathrm{CF}$. Because StAR is thought to mediate ACTH-induced cortisol production by facilitating cholesterol flux into mitochondria (Miller, 2017), the downregulated StAR expression in CM suggests potential changes in stress- induced steroidogenesis in calves under such colostrum feeding management. Meanwhile, the expression of CYP11B1 encoding rate-limiting enzyme in cortisol synthesis in adrenal glands was not affected by feeding treatments. Plasma concentrations of cortisol were also not significantly different between feeding treatments. Thus, CM feeding after the first colostrum meal was suggested to have minor effects on cortisol production detected in sera, but it is unknown whether the cortisol production might be affected in adrenal glands. Our results also showed that $\mathrm{CF}$ calves had a higher expression of ADRA1A in adrenal glands. Schäff et al. (2014) reported that calves fed colostrum tended to have higher binding capacity of glucocorticoid and $\alpha_{1}$-adrenergic receptors in the liver compared with calves that received milk-based formula. It has been proposed that such stimulation of adrenergic receptors via catecholamines binding in the calf's liver is involved in modulating glucose metabolism (Carron et al., 2005; Schäff et al., 2014). However, whether colostrum directly affects the expression of adrenergic receptors in adrenal glands, a main location of catecholamine production, is currently unknown. Our results suggest that extended colostrum feeding to avoid a sharp transition from a colostrum to milk may stimulate expression of adrenal $\alpha_{1}$-adrenergic receptors in calf adrenal glands.

In addition to the adrenal glands, different colostrum feeding strategies also changed the expression of neuroendocrine genes in the intestinal tract of calves, especially those related to glucocorticoids, catecholamine and serotonin signaling. Extended colostrum feeding tended to induce higher expression of $A D R A 1 A$ in the ileum, which corresponds to the similar results in the adrenal glands. However, the expression of $A D R A 1 A$ in 
the colon was higher in calves that were subsequently fed WM. These results could be attributed to colostrum and milk-derived components stimulating $\alpha_{1}$-adrenergic receptors in the ileum and colon, respectively. Although the precise mechanism causing this inconsistent expressional change was not clear, the altered expression of $A D R A 1 A$ in all 3 tissues suggests that colostrum feeding may affect adrenergic receptor mediated gut function, such as gut vermiculation. In addition, calves fed the $\mathrm{CF}$ diet tended to have increased expression of serotonin receptor (HTR4) and transporter (SLC6A4) in the ileum, whereas plasma serotonin concentration was not different. Although our data of blood serotonin concentrations seemed to be lower compared with some studies, other papers showed similar or comparative results (Watanabe et al., 2014; Weaver et al., 2016). Interestingly, serotonin concentration is reported to decrease after birth, reaching the lowest level at 2 to 3 d of age (Hernández-Castellano et al., 2018), which suggests attenuated serotonin signaling in newborn calves. Our result suggests that prolonged ingestion of colostrum may reinforce serotonin-mediated signaling in the ileum locally. Previous reports also suggest a potential interaction between catecholamines and serotonin due to the overlapping nerve fibers of these neurotransmitters (Kim and Camilleri, 2000; Hensler et al., 2013), suggesting that serotonin-modulated signaling in the ileum could interplay with signaling induced by the $\alpha_{1}$-adrenergic receptor. In addition, the expression of $N R 3 C 1$ and MC2R was higher in the ileum and colon, respectively, under WM and CM feeding compared with that under CF. From this result, it is speculated that the higher concentration of cortisol in colostrum than milk (Shutt and Fell, 1985) decreased the expression of NR3C1 in ileum epithelial cells, as cortisol treatment was reported to downregulate $N R 3 C 1$ mRNA level in some cell types, including enterocytes (Numakawa et al., 2009; Pang et al., 2014). Further studies are needed to compare the cortisol concentrations between milk and colostrum, and to investigate the role of these genes and their encoded proteins in affecting the physiological alterations and gut development of neonatal calves, and the possible signaling interactions of serotonin, adrenergic, and glucocorticoid receptors.
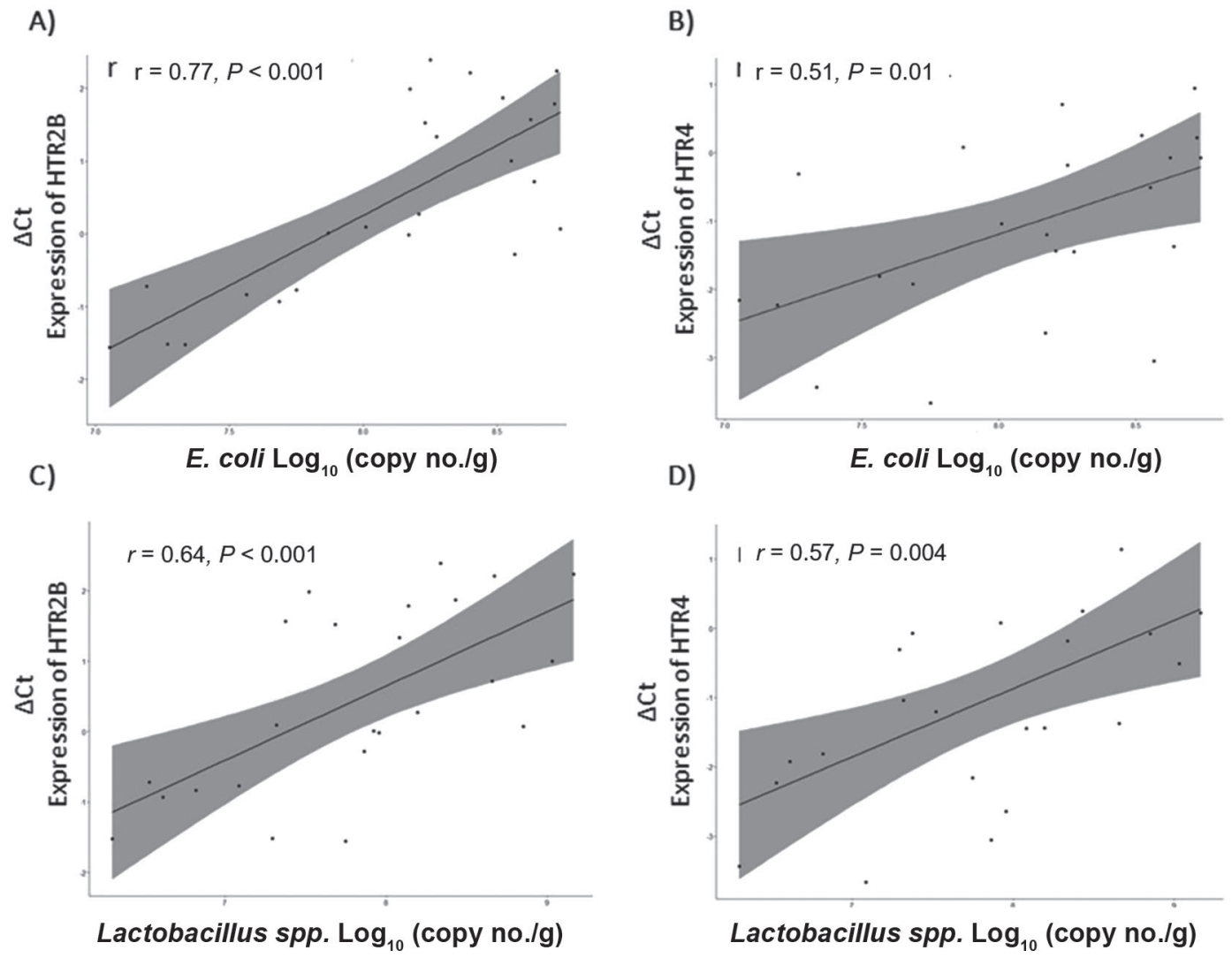

Figure 4. Pearson correlation between log-transformed abundance of active tissue-associated gut bacteria and gene expression $(\Delta \mathrm{Ct}$; $\mathrm{Ct}=$ cycle threshold) of serotonin receptors in the colon of neonatal calves. The correlation between Escherichia coli and HTR2B (A), E. coli and HTR4 (B), Lactobacillus spp. and HTR2B (C), and Lactobacillus spp. and HTR4 (D) are indicated. Gray area shows $95 \%$ confidence limits. 
Emerging evidence has revealed the relationship between gut bacteria and host neuroendocrine function in recent studies (Sandrini et al., 2015; Farzi et al., 2018), highlighting the effect of gut microbiota on the gut-brain axis. In the present study, we observed that prolonged colostrum feeding increased the abundance of active tissue-associated Lactobacillus spp. in the ileum and colon, and the abundance of active tissueassociated E. coli in colon compared with WM and $\mathrm{CM}$ as subsequent meals. Colostrum generally contains higher concentrations of casein and lactoferrin than milk (McGrath et al., 2016), which have been shown to promote growth of Lactobacillus species (Artym and Zimecki, 2005). Fischer et al. (2018) found that calves fed colostrum immediately after birth had higher total E. coli prevalence compared with calves not fed colostrum until $6 \mathrm{~h}$ or $12 \mathrm{~h}$ after birth. Additionally, the identified strong positive correlation between abundance of active Lactobacillus spp. and active E. coli suggests a potential association of these 2 bacterial groups. Interestingly, the positive correlations between the expression of HTR4 and HTR2B and both bacterial groups were also detected in colon tissues. A recent study using germ-free and gnotobiotic mice has shown that commensal bacteria can produce serotonin in the gut lumen in vivo (Hata et al., 2017). More specifically, it was reported that several different Lactobacillus spp. produce serotonin, dopamine, and other hormone-like metabolites, and this ability was enhanced in the presence of gram-negative bacteria, including E. coli (Özoğul et al., 2012). It has been reported that serum cortisol level significantly increased when mice were challenged with E. coli O157 (Forsythe et al., 2010). Indeed, moderate correlation $(\mathrm{r}=0.415, P=0.044)$ was detected between abundance of active mucosa-attached $E$. coli in the ileum and plasma cortisol, suggesting that increasing the abundance of potential pathogenic E. coli lead to higher stress of calves. However, the E. coli detected in this study is generic, and future studies to profile $E$. coli at strain/seroptype level are needed to verify those that may be beneficial (stimulating growth of Lactobacilli) or unbeneficial (pathogenic) to newborn calves. Nevertheless, the present findings suggest a potential interaction between active tissue-associated E. coli and Lactobacillus spp. and host neurotransmitter receptor gene expression, and potentially endocrine gene expression. Future research should focus on the causal effects of region-dependent changes observed in this study to better understand the interaction between microbehost neuroendocrine function. Because there were no significant correlations observed between gut bacteria and expression of genes encoding host neurotransmitter receptors in the ileum, we speculate that the interactions between gut bacteria and host endocrine receptors differ among varied gut regions due to the variations in the abundance of gut microbes and gut environmental properties, such as lower $\mathrm{pH}$ and thinner mucus in the small intestine.

\section{CONCLUSIONS}

The present study detected and characterized the expression of genes involved in neuroendocrine functions in intestinal tissues, as well as in the adrenal gland of neonatal dairy calves. The altered expression of these neuroendocrine genes in adrenal glands and ileum and colon tissues and altered active mucosaattached Lactobacillus spp. and E. coli were detected under different colostrum and milk feeding strategies. These suggest the effect of different colostrum feeding management on the expressional regulation of neuroendocrine genes, which is partly mediated by the alteration of gut microbiota. Future studies are required to understand the specific colostrum and milk-derived components that can influence microbiota and its production of neurotransmitter-like molecules, and the molecular mechanism in the interaction between gutassociated bacteria and host neuroendocrine function in newborn calves. In addition to the well-characterized bioactives, such as IgG, oligosaccharides, or peptides, in colostrum and milk, endocrine molecules may also differ in colostrum replacer, maternal, pasteurized, and nonpasteurized colostrum, which has not been studied to date. Such variation may also affect microbiota and gut gene expression related to gut-brain axis, which warrants further study. The knowledge obtained from this study provides a better understanding of neonatal neuroendocrine function in the gut of newborn calves, which might play an essential role in the development of gut function during early life. The knowledge generated from this study is vital to assist the industry in developing better management strategies to improve neonatal calf gut health.

\section{ACKNOWLEDGMENTS}

This project is funded by Alberta Agriculture and Forestry (2015B013R), the Natural Sciences and Engineering Research Council of Canada (Discovery grant) and supported in part by Chinese Scholarship Council to T. Ma. The authors also thank the staff at Dairy Research Technology Centre (University of Alberta), L. Grenwich, Z. He, Y. Song, E. O'Hara, H. Sun, A. Bulumulla, A. Luis Neves, A. Fischer, and J. Liu (University 
of Alberta) for their assistance with animal experiments and sample collection. The authors have not stated any conflicts of interests.

\section{REFERENCES}

Allen, A. P., W. Hutch, Y. E. Borre, P. J. Kennedy, A. Temko, G. Boylan, E. Murphy, J. F. Cryan, T. G. Dinan, and G. Clarke. 2016. Bifidobacterium longum 1714 as a translational psychobiotic: Modulation of stress, electrophysiology and neurocognition in healthy volunteers. Transl. Psychiatry 6:e939. https://doi.org/10 .1038/tp.2016.191.

Artym, J., and M. Zimecki. 2005. The role of lactoferrin in the proper development of newborns. Postepy Hig. Med. Dosw. 59:421-432.

Bendixen, E., M. Danielsen, K. Hollung, E. Gianazza, and I. Miller. 2011. Farm animal proteomics - A review. J. Proteomics 74:282293. https://doi.org/10.1016/j.jprot.2010.11.005.

Blum, J. W. 2006. Nutritional physiology of neonatal calves. J. Anim. Physiol. Anim. Nutr. (Berl.) 90:1-11. https://doi.org/10.1111/j .1439-0396.2005.00614.x.

Burrin, D. G., B. Stoll, and X. Guan. 2003. Glucagon-like peptide 2 function in domestic animals. Domest. Anim. Endocrinol. 24:103122. https://doi.org/10.1016/S0739-7240(02)00210-2.

Carron, J., C. Morel, H. M. Hammon, and J. W. Blum. 2005. Ontogenetic development of mRNA levels and binding sites of hepatic $\beta$-adrenergic receptors in cattle. Domest. Anim. Endocrinol. 28:320-330. https://doi.org/10.1016/j.domaniend.2004.12.002.

Charavaryamath, C., P. Fries, S. Gomis, C. Bell, K. Doig, L. L. Guan, A. Potter, S. Napper, and P. J. Griebel. 2011. Mucosal changes in a long-term bovine intestinal segment model following removal of ingesta and microflora. Gut Microbes 2:134-144. https://doi.org/ 10.4161/gmic.2.3.16483.

Cima, I., N. Corazza, B. Dick, A. Fuhrer, S. Herren, S. Jakob, E. Ayuni, C. Mueller, and T. Brunner. 2004. Intestinal epithelial cells synthesize glucocorticoids and regulate T cell activation. J. Exp. Med. 200:1635-1646. https://doi.org/10.1084/jem.20031958.

Cleusix, V., C. Lacroix, G. Dasen, M. Leo, and G. Le Blay. 2010. Comparative study of a new quantitative real-time PCR targeting the xylulose-5-phosphate/fructose-6-phosphate phosphoketolase bifidobacterial gene $(x f p)$ in faecal samples with two fluorescence in situ hybridization methods. J. Appl. Microbiol. 108:181-193. https://doi.org/10.1111/j.1365-2672.2009.04408.x.

Connor, E. E., C. M. Evock-Clover, M. P. Walker, T. H. Elsasser, and S. Kahl. 2015. Comparative gut physiology symposium: Comparative physiology of glucagon-like peptide-2: Implications and applications for production and health of ruminants. J. Anim. Sci. 93:492-501. https://doi.org/10.2527/jas.2014-8577.

Corominas, R., M. J. Sobrido, M. Ribasés, E. Cuenca-León, P. BlancoArias, B. Narberhaus, M. Roig, R. Leira, J. López-González, A. Macaya, and B. Cormand. 2010. Association study of the serotoninergic system in migraine in the Spanish population. Am. J. Med. Genet. B. Neuropsychiatr. Genet. 153B:177-184.

Delroisse, J. M., A. L. Boulvin, I. Parmentier, R. D. Dauphin, M. Vandenbol, and D. Portetelle. 2008. Quantification of Bifidobacterium spp. and Lactobacillus spp. in rat fecal samples by realtime PCR. Microbiol. Res. 163:663-670. https://doi.org/10.1016/ j.micres.2006.09.004.

Drucker, D. J. 2001. Glucagon-like peptide 2. J. Clin. Endocrinol. Metab. 86:1759-1764.

Eisenhofer, G., A. Åneman, P. Friberg, D. Hooper, L. Fåndriks, H. Lonroth, B. Hunyady, and E. Mezey. 1997. Substantial production of dopamine in the human gastrointestinal tract. J. Clin. Endocrinol. Metab. 82:3864-3871. https://doi.org/10.1210/jcem.82.11 .4339 .

Farzi, A., E. E. Fröhlich, and P. Holzer. 2018. Gut microbiota and the neuroendocrine system. Neurotherapeutics 15:5-22. https:// doi.org/10.1007/s13311-017-0600-5.

Fischer, A. J., Y. Song, Z. He, D. M. Haines, L. L. Guan, and M. A. Steele. 2018. Effect of delaying colostrum feeding on passive trans- fer and intestinal bacterial colonization in neonatal male Holstein calves. J. Dairy Sci. 101:3099-3109. https://doi.org/10.3168/jds .2017-13397.

Forsythe, P., N. Sudo, T. Dinan, V. H. Taylor, and J. Bienenstock. 2010. Mood and gut feelings. Brain Behav. Immun. 24:9-16. https: //doi.org/10.1016/j.bbi.2009.05.058.

Hadorn, U., H. Hammon, R. M. Bruckmaier, and J. W. Blum. 1997. Delaying colostrum intake by one day has important effects on metabolic traits and on gastrointestinal and metabolic hormones in neonatal calves. J. Nutr. 127:2011-2023. https://doi.org/10 $.1093 /$ jn/127.10.2011.

Hammon, H. M., G. Schiessler, A. Nussbaum, and J. W. Blum. 2002. Feed intake patterns, growth performance, and metabolic and endocrine traits in calves fed unlimited amounts of colostrum and milk by automate, starting in the neonatal period. J. Dairy Sci. 85:3352-3362. https://doi.org/10.3168/jds.S0022-0302(02)74423 $-8$.

Hammon, H. M., J. Steinhoff-Wagner, J. Flor, U. Schönhusen, and C. C. Metges. 2013. Lactation biology symposium: Role of colostrum and colostrum components on glucose metabolism in neonatal calves. J. Anim. Sci. 91:685-695. https://doi.org/10.2527/jas.2012 -5758 .

Hata, T., Y. Asano, K. Yoshihara, T. Kimura-Todani, N. Miyata, X.T. Zhang, S. Takakura, Y. Aiba, Y. Koga, and N. Sudo. 2017. Regulation of gut luminal serotonin by commensal microbiota in mice. PLoS One 12:e0180745. https://doi.org/10.1371/journal .pone.0180745.

Hensler, J. G., F. Artigas, A. Bortolozzi, L. C. Daws, P. De Deurwaerdère, L. Milan, S. Navailles, and W. Koek. 2013. Catecholamine/Serotonin interactions: systems thinking for brain function and disease. Adv. Pharmacol. 68:167-197. https://doi.org/10 .1016/B978-0-12-411512-5.00009-9.

Hernández-Castellano, L. E., R. Özçelik, L. L. Hernandez, and R. M. Bruckmaier. 2018. Supplementation of colostrum and milk with 5-hydroxy-l-tryptophan affects immune factors but not growth performance in newborn calves. J. Dairy Sci. 101:794-800. https:/ /doi.org/10.3168/jds.2017-13501.

Hodge, E., C. P. Nelson, S. Miller, C. K. Billington, C. E. Stewart, C. Swan, A. Malarstig, A. P. Henry, C. Gowland, E. Melén, I. P. Hall, and I. Sayers. 2013. HTR4 gene structure and altered expression in the developing lung. Respir. Res. 14:77. https://doi.org/10.1186/ 1465-9921-14-77.

Hulbert, L. E., and S. J. Moisá. 2016. Stress, immunity, and the management of calves. J. Dairy Sci. 99:3199-3216. https://doi.org/10 $.3168 /$ jds.2015-10198.

Inabu, Y., J. Pyo, S. Pletts, L. L. Guan, M. A. Steele, and T. Sugino. 2019. Effect of extended colostrum feeding on plasma glucagon-like peptide-1 concentration in newborn calves. J. Dairy Sci. 102:4619 4627. https://doi.org/10.3168/jds.2018-15616.

Juszczak, G. R., and A. M. Stankiewicz. 2018. Glucocorticoids, genes and brain function. Prog. Neuropsychopharmacol. Biol. Psychiatry 82:136-168. https://doi.org/10.1016/j.pnpbp.2017.11.020.

Kim, D. Y., and M. Camilleri. 2000. Serotonin: A mediator of the brain-gut connection. Am. J. Gastroenterol. 95:2698-2709.

Kostadinova, F., J. Schwaderer, V. Sebeo, and T. Brunner. 2014. Why does the gut synthesize glucocorticoids? Ann. Med. 46:490-497. https://doi.org/10.3109/07853890.2014.932920.

Kuhn, R. M., D. Haussler, and W. J. Kent. 2013. The UCSC genome browser and associated tools. Brief. Bioinform. 14:144-161. https: //doi.org/10.1093/bib/bbs038.

Kühne, S., H. M. Hammon, R. M. Bruckmaier, C. Morel, Y. Zbinden, and J. W. Blum. 2000. Growth performance, metabolic and endocrine traits, and absorptive capacity in neonatal calves fed either colostrum or milk replacer at two levels. J. Anim. Sci. 78:609-620. https://doi.org/10.2527/2000.783609x.

Li, J., X.-M. Yang, Y.-H. Wang, M.-X. Feng, X.-J. Liu, Y.-L. Zhang, S. Huang, Z. Wu, F. Xue, W.-X. Qin, J.-R. Gu, Q. Xia, and Z.G. Zhang. 2014. Monoamine oxidase A suppresses hepatocellular carcinoma metastasis by inhibiting the adrenergic system and its transactivation of EGFR signaling. J. Hepatol. 60:1225-1234. https://doi.org/10.1016/j.jhep.2014.02.025. 
Liu, Y., L. I. Smith, V. Huang, V. Poon, A. Coello, M. Olah, F. Spiga, S. L. Lightman, and G. Aguilera. 2013. Transcriptional regulation of episodic glucocorticoid secretion. Mol. Cell. Endocrinol. 371:62-70. https://doi.org/10.1016/j.mce.2012.10.011.

Lyte, M., L. Vulchanova, and D. R. Brown. 2011. Stress at the intestinal surface: Catecholamines and mucosa-bacteria interactions. Cell Tissue Res. 343:23-32. https://doi.org/10.1007/s00441-010 $-1050-0$.

Malmuthuge, N., Y. Chen, G. Liang, L. A. Goonewardene, and L. L. Guan. 2015. Heat-treated colostrum feeding promotes beneficial bacteria colonization in the small intestine of neonatal calves. J. Dairy Sci. 98:8044-8053. https://doi.org/10.3168/jds.2015-9607.

McGrath, B. A., P. F. Fox, P. L. H. McSweeney, and A. L. Kelly. 2016. Composition and properties of bovine colostrum: A review. Dairy Sci. Technol. 96:133-158. https://doi.org/10.1007/s13594 -015-0258-x.

Miller, W. L. 2017. Steroidogenesis: Unanswered questions. Trends Endocrinol. Metab. 28:771-793. https://doi.org/10.1016/j.tem 2017.09.002.

Moya-Pérez, A., A. Perez-Villalba, A. Benítez-Páez, I. Campillo, and Y. Sanz. 2017. Bifidobacterium CECT 7765 modulates early stress-induced immune, neuroendocrine and behavioral alterations in mice. Brain Behav. Immun. 65:43-56. https://doi.org/10.1016/ j.bbi.2017.05.011.

Mulder, I. E., B. Schmidt, M. Lewis, M. Delday, C. R. Stokes, M. Bailey, R. I. Aminov, B. P. Gill, J. R. Pluske, C. D. Mayer, and D. Kelly. 2011. Restricting microbial exposure in early life negates the immune benefits associated with gut colonization in environments of high microbial diversity. PLoS One 6:e28279. https://doi.org/10 .1371/journal.pone.0028279.

Noti, M., D. Sidler, and T. Brunner. 2009. Extra-adrenal glucocorticoid synthesis in the intestinal epithelium: More than a drop in the ocean? Semin. Immunopathol. 31:237-248. https://doi.org/10 .1007/s00281-009-0159-2.

Numakawa, T., E. Kumamaru, N. Adachi, Y. Yagasaki, A. Izumi, and H. Kunugi. 2009. Glucocorticoid receptor interaction with TrkB promotes BDNF-triggered PLC- $\gamma$ signaling for glutamate release via a glutamate transporter. Proc. Natl. Acad. Sci. USA 106:647652. https://doi.org/10.1073/pnas.0800888106.

Nutt, D. J., P. Blier, D. Seripa, A. Pilotto, G. Paroni, A. Fontana, G. D'Onofrio, C. Gravina, M. Urbano, L. Cascavilla, F. Paris, F. Panza, A. Padovani, and A. Pilotto. 2015. Role of the serotonin transporter gene locus in the response to SSRI treatment of major depressive disorder in late life. J. Psychopharmacol. 29:623-633. https://doi.org/10.1177/0269881115578159.

Özoğul, F., E. Kuley, Y. Özoğul, and I. Özoğul. 2012. The function of lactic acid bacteria on biogenic amines production by food-borne pathogens in arginine decarboxylase broth. Food Sci. Technol. Res. 18:795-804. https://doi.org/10.3136/fstr.18.795.

Pacak, K. 2011. Pheochromocytoma: A catecholamine and oxidative stress disorder. Endocr. Regul. 45:65-90. https://doi.org/10.4149/ endo_2011_02_65.

Pang, S., H. Wu, Q. Wang, M. Cai, W. Shi, and J. Shang. 2014. Chronic stress suppresses the expression of cutaneous hypothalamic-pituitary-adrenocortical axis elements and melanogenesis. PLoS One 9:e98283. https://doi.org/10.1371/journal.pone.0098283.

Proudnikov, D., S. Hamon, J. Ott, and M. J. Kreek. 2008. Association of polymorphisms in the melanocortin receptor type 2 (MC2R, $\mathrm{ACTH}$ receptor) gene with heroin addiction. Neurosci. Lett. 435:234-239. https://doi.org/10.1016/j.neulet.2008.02.042.

Pyo, J., K. Hare, S. Pletts, Y. Inabu, D. Haines, T. Sugino, L. L. Guan, and M. Steele. 2020. Feeding colostrum or a 1:1 colostrum: milk mixture for $3 \mathrm{~d}$ postnatal increases small intestinal development and minimally influences plasma glucagon-like peptide-2 and serum insulin-like growth factor-1 concentrations in Holstein bull calves. J. Dairy Sci. https://doi.org/10.3168/jds.2019-17219 103:4236-4251.

Sabat, G., P. Rose, W. J. Hickey, and J. M. Harkin. 2000. Selective and sensitive method for PCR amplification of Escherichia coli 16S rRNA genes in soil. Appl. Environ. Microbiol. 66:844-849. https:/ /doi.org/10.1128/AEM.66.2.844-849.2000.
Sandrini, S., M. Aldriwesh, M. Alruways, and P. Freestone. 2015. Microbial endocrinology: Host-bacteria communication within the gut microbiome. J. Endocrinol. 225:R21-R34. https://doi.org/10 $.1530 / \mathrm{JOE}-14-0615$.

Santulli, G., A. Lombardi, D. Sorriento, A. Anastasio, C. Del Giudice, P. Formisano, F. Béguinot, B. Trimarco, C. Miele, and G. Iaccarino. 2012. Age-related impairment in insulin release: The essential role of $\beta_{2}$-adrenergic receptor. Diabetes 61:692-701. https://doi .org/10.2337/db11-1027.

Scanzano, A., and M. Cosentino. 2015. Adrenergic regulation of innate immunity: A review. Front. Pharmacol. 6:171. https://doi.org/10 .3389/fphar.2015.00171.

Schäff, C. T., D. Rohrbeck, J. Steinhoff-Wagner, E. Kanitz, H. Sauerwein, R. M. Bruckmaier, and H. M. Hammon. 2014. Effects of colostrum versus formula feeding on hepatic glucocorticoid and $\alpha_{1^{-}}$and $\beta_{2^{-}}$adrenergic receptors in neonatal calves and their effect on glucose and lipid metabolism. J. Dairy Sci. 97:6344-6357. https: //doi.org/10.3168/jds.2014-8359.

Schmittgen, T. D., and B. A. Zakrajsek. 2000. Effect of experimental treatment on housekeeping gene expression: Validation by realtime, quantitative RT-PCR. J. Biochem. Biophys. Methods 46:6981. https://doi.org/10.1016/S0165-022X(00)00129-9.

Shutt, D. A., and L. R. Fell. 1985. Comparison of total and free cortisol in bovine serum and milk or colostrum. J. Dairy Sci. 68:1832-1834. https://doi.org/10.3168/jds.S0022-0302(85)81035-3.

Smith, P. A. 2015. The tantalizing links between gut microbes and the brain. Nature 526:312-314. https://doi.org/10.1038/526312a.

Smith, S. M., and W. W. Vale. 2006. The role of the hypothalamicpituitary-adrenal axis in neuroendocrine responses to stress. Dialogues Clin. Neurosci. 8:383-395.

Song, Y., N. Malmuthuge, F. Li, and L. L. Guan. 2019. Colostrum feeding shapes the hindgut microbiota of dairy calves during the first $12 \mathrm{~h}$ of life. FEMS Microbial. Ecol. 95:fiy203. https://doi.org/ 10.1093/femsec/fiy203.

Spohn, S. N., F. Bianco, R. B. Scott, C. M. Keenan, A. A. Linton, C. H. O'Neill, E. Bonora, M. Dicay, B. Lavoie, R. L. Wilcox, W. K. MacNaughton, R. De Giorgio, K. A. Sharkey, and G. M. Mawe. 2016. Protective actions of epithelial 5-hydroxytryptamine 4 receptors in normal and inflamed colon. Gastroenterology 151:933-944. https://doi.org/10.1053/j.gastro.2016.07.032.

Stevenson, D. M., and P. J. Weimer. 2007. Dominance of Prevotella and low abundance of classical ruminal bacterial species in the bovine rumen revealed by relative quantification real-time PCR. Appl. Microbiol. Biotechnol. 75:165-174. https://doi.org/10.1007/ s00253-006-0802-y.

Tharayil, V. S., M. M. Wouters, J. E. Stanich, J. L. Roeder, S. Lei, A. Beyder, P. J. Gomez-Pinilla, M. D. Gershon, L. Maroteaux, S. J. Gibbons, and G. Farrugia. 2010. Lack of serotonin 5- $\mathrm{HT}_{2 \mathrm{~B}}$ receptor alters proliferation and network volume of interstitial cells of Cajal in vivo. Neurogastroenterol. Motil. 22:462-469. https://doi.org/10 .1111/j.1365-2982.2009.01435.x.

Toni, R. 2004. The neuroendocrine system: Organization and homeostatic role. J. Endocrinol. Invest. 27:35-47.

Vasseur, E., F. Borderas, R. I. Cue, D. Lefebvre, D. Pellerin, J. Rushen, K. M. Wade, and A. M. de Passillé. 2010. A survey of dairy calf management practices in Canada that affect animal welfare. J. Dairy Sci. 93:1307-1316. https://doi.org/10.3168/jds.2009-2429.

Wang, Q., T. Ishikawa, T. Michiue, B.-L. Zhu, D.-W. Guan, and H. Maeda. 2012. Stability of endogenous reference genes in postmortem human brains for normalization of quantitative real-time PCR data: Comprehensive evaluation using geNorm, NormFinder, and BestKeeper. Int. J. Legal Med. 126:943-952. https://doi.org/10 .1007/s00414-012-0774-7.

Watanabe, H., R. Saito, T. Nakano, H. Takahashi, Y. Takahashi, K. Sumiyoshi, K. Sato, X. Chen, N. Okada, S. Iwasaki, D. W. Harjanti, N. Sekiguchi, H. Sano, H. Kitazawa, M. T. Rose, S. Ohwada, K. Watanabe, and H. Aso. 2014. Effect of peripheral 5-HT on glucose and lipid metabolism in wether sheep. PLoS One 9:e88058. https://doi.org/10.1371/journal.pone.0088058.

Weaver, D. M., J. W. Tyler, D. C. VanMetre, D. E. Hostetler, and G. M. Barrington. 2000. Passive transfer of colostral immunoglobulins 
in calves. Vet. Intern. Med. 14:569-577. https://doi.org/10.1111/j .1939-1676.2000.tb02278.x.

Weaver, S. R., A. P. Prichard, E. L. Endres, S. A. Newhouse, T. L. Peters, P. M. Crump, M. S. Akins, T. D. Crenshaw, R. M. Bruckmaier, and L. L. Hernandez. 2016. Elevation of circulating serotonin improves calcium dynamics in the peripartum dairy cow. J. Endocrinol. 230:105-123. https://doi.org/10.1530/JOE-16-0038.

Zhao, X., S. Qin, Y. Shi, A. Zhang, J. Zhang, L. Bian, C. Wan, G. Feng, N. Gu, G. Zhang, G. He, and L. He. 2007. Systematic study of association of four GABAergic genes: Glutamic acid decarboxylase 1 gene, glutamic acid decarboxylase 2 gene, $\mathrm{GABA}_{\mathrm{B}}$ receptor 1 gene and $\mathrm{GABA}_{\mathrm{A}}$ receptor subunit $\beta_{2}$ gene, with schizophrenia using a universal DNA microarray. Schizophr. Res. 93:374-384. https://doi.org/10.1016/j.schres.2007.02.023.

Zaros, L. G., P. A. Bricarello, A. F. T. Amarante, and L. L. Coutinho, 2007. Quantification of bovine cytokine gene expression using real- time RT-PCR methodology. Genet. Mol. Biol. 30:575-579. https:/ /doi.org/10.1590/S1415-47572007000400012.

\section{ORCIDS}

Jitka Hromádková @ https://orcid.org/0000-0002-9202-9745

Yutaka Suzuki @ https://orcid.org/0000-0002-0768-2548

Sarah Pletts @ https://orcid.org/0000-0002-2167-9636

Jade Pyo (i) https://orcid.org/0000-0002-2111-0968

Tao Ma @ https://orcid.org/0000-0003-4821-836X

Michael A. Steele @ https://orcid.org/0000-0001-6941-6205

Le Luo Guan ำ https://orcid.org/0000-0002-8420-4371 